\title{
Evaluation method for Engineering Program Assessment to implement OBE (Outcome Bases Education) System in Engineering Colleges
}

\author{
T. Asha Latha \\ Anurag Group of Institutions \\ JNTUH \\ Hyderabad, India
}

\author{
N. Naga Lakshmi \\ Anurag Group of Institutions \\ JNTUH \\ Hyderabad, India
}

\author{
Dr. A. Prashanth Rao \\ Anurag Group of Institutions \\ JNTUH \\ Hyderabad, India
}

\begin{abstract}
All Indian Engineering Institutions of higher education learning to adopt the outcome based education (OBE). The OBE is an educational process that emphasis achieving specified outcome in terms of individual study learning. All teaching staffs and students are directly involved with this. As for the students, they have been introduced with OBE from the day they registered, in all teaching and learning activities until they graduated. Teaching staffs are required to produce the Program Outcomes (PO) and Program Educational Objectives (PEO) in every teaching plan. This paper is mainly focus on first year to fourth year students of Bachelor of Information Technology assessment report for each student. The two methods direct and indirect has to be used and propped template created which gives better performance.
\end{abstract}

Keywords: Outcome Based, Program Outcomes, Program Educational Objectives

\section{INTRODUCTION}

As a solution, All India Council for Technical Education (AICTE) under the preview of Board of Engineers India has steering the OBE [1]. OBE is an educational process that emphasis achieving specified outcome in terms of individual study earning. The specified outcome relates knowledge, skills and attitudes. OBE is an essential requirement for Indian institution to become a full signatory member of multinational agreement for the mutual recognition of engineering bachelor degree.

In OBE, the educational outcomes are clearly and unambiguously specified. These determine the curriculum content and its organization, the teaching methods and strategies, the courses offered, the assessment process, the educational environment and the curriculum timetable. An engineer is a unique combination of different kinds of knowledge, skills and attitudes. In Spady's words: "Outcome Based Education means clearly focusing and organizing everything in an educational system around what is essential for all students to be able to do successfully at the end of their learning experiences. This means starting with a clear picture of what is important for students to be able to do, then organizing the curriculum, instruction, and assessment to make sure this learning ultimately happens. OBE is a wonderful system of education which makes the students industry-ready once they have graduated, though initially the faculty and students have to put more efforts and many hours of hard work in materials preparations and evidence collection. OBE System is not diluted into Tier-I and Tier-II Systems. OBE System is only one - and has to be implemented wholeheartedly, without any deviations, regardless of whether the institutes are autonomous or affiliated.

The eleven generic attributes refers to science mathematics and engineering knowledge (PO1), problems identification and problem solving (PO2), ability to design and development of solutions (PO3), conduct investigations of complex problems (PO4), create and apply Modern appropriate techniques (PO5), understand the engineer and society (PO6), understanding of the social, cultural, global and environmental responsibilities(PO7), understanding, responsible and commit with professional ethic (PO8), teamwork and leadership (PO9), communication skill (P010), Project management and finance (PO11), and life-long learning (PO12). NBA (National Board of Accreditation) also acts as an accreditation awarding body for all engineering 
program in India. Therefore, emphasis of OBE has been lined out in order to achieve national vision.

Nevertheless, every Program Educational Outcome (PEO) and Program Outcomes (PO) performs need to be analyzed and continuous quality improvement (CQI) should be done for future enhancement.

\section{RESEARCH METHODOLOGY}

This paper is mainly focus of engineering students from first year to fourth year. The research has divided in to two parts: direct assessment method and indirect assessment method. The evaluation marks of the assessment are total up and converted in to three scaling. Then the results are illustrated in bar charts so that the analysis of a engineering program can be thoroughly done.

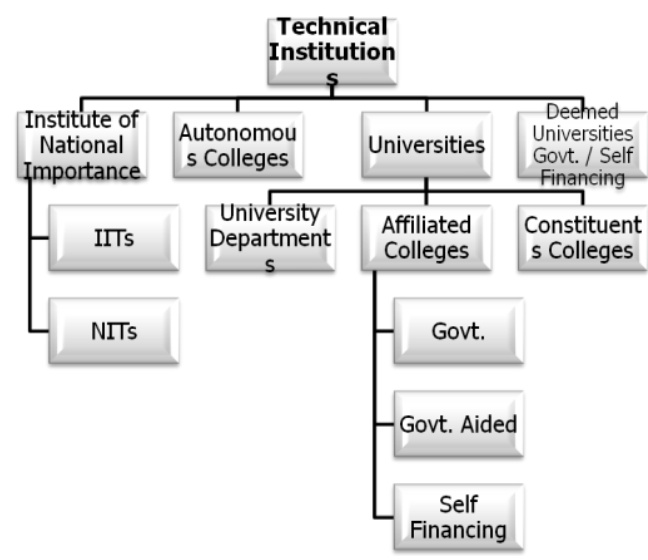

\section{A. Direct Survey}

Direct survey has categorized into two components which is student exam assessment survey and course end survey. Student assessment survey covers the whole semester coursework and the final examination. The coursework includes individual internal examinations, assignment, external examinations, mini project, Seminars, Main project presentation and laboratory report. End of semester survey evaluates the achievements of PO and PEO fixed by the lecturer at the beginning of the semester. It ranked from three (the highest) and one (the lowest). The percentage of direct survey is the average of students' assessment survey and end of semester survey.

\section{Algorithm for Direct Assessment:}

1. Identify and select class for a given department

2. For each class a. Select section and for each section repeat the following

b. Initialize number of students for selected section $=\mathrm{n}$

i. for (int $\mathrm{i}=0 ; \mathrm{i}<\mathrm{n} ; \mathrm{i}++) / /$ for each student perform the following //

ii. for ( int $\mathrm{j}=1 ; \mathrm{j}<\mathrm{k} ; \mathrm{k}++) / /$ for each each subject and initialize number of subjects equal to $\mathrm{k} / /$

Compute course outcome for each subject

iii. Compute the average course outcome for a given section

3. Increment section and repeat step b

4. Compute average course outcome of a given class

5. Increment class index and repeat step 2 to 4

6. Compute Program Outcome for each department

Compute Program Educational Objective of the department

\section{B. Indirect Survey}

Indirect survey is also divided into two: course end survey and alumni survey. Course end survey is evaluated based on Course outcomes rating from each course end survey form which is designed by the institution .In OBE approach each parameter is weighted 1 (lowest) to 3(highest). Alumni survey can only be conducted four years after the students graduate. As for this research, the fourth year students will be graduated by middle of 2013. Therefore, alumni survey will be conducted in 2014. Results for alumni survey will be analyzed once the survey has been conducted.

\section{Algorithm for Indirect Assessment:}

1. Identify and select class for a given department

2. For each class

a. Select section and for each section repeat the following

b. Initialize number of students for selected section $=\mathrm{n}$

i. for (int $\mathrm{i}=0 ; \mathrm{i}<\mathrm{n} ; \mathrm{i}++) / /$ for each student perform the following //

ii. for $($ int $\mathrm{j}=1 ; \mathrm{j}<\mathrm{k} ; \mathrm{k}++) / /$ for each subject and initialize number of subjects equal to $\mathrm{k} / /$ Compute $\mathrm{CO}$ for each exit survey, course-end survey

iii. Compute the average course outcome for a given section

3. Increment section and repeat step b

4. Compute average course outcome of a given class

5. Increment class index and repeat step 2 to 4

6. Compute Program Outcome for each department

Compute Program Educational Objective of the department 


\section{RESULTS ANALYSIS}

The results are analyzed in detail based on Year of study and overall analysis for the whole for each subject of engineering program.

The results format is as follows.

\section{Direct/ Indirect Assessment Sheet}

Batch:

Academic Year/Sem:

Course Name:

Course Number:

Course Outcomes:

MID-I Exam Assessment:

Number of Students Appeared:

A:

\begin{tabular}{|l|c|c|c|c|c|c|c|}
\hline Assessment & $\begin{array}{c}\text { Threshold } \\
\text { value }\end{array}$ & $\begin{array}{c}\text { Actual } \\
\text { Average }\end{array}$ & $\begin{array}{c}\text { (3) } \\
\text { Target \% of } \\
\text { students on } \\
\text { or above } \\
\text { threshold }\end{array}$ & $\begin{array}{c}\text { (4) } \\
\text { Target No. of } \\
\text { students on or } \\
\text { above } \\
\text { Threshold }\end{array}$ & $\begin{array}{c}\text { (5) } \\
\text { Actual \% of } \\
\text { students on or } \\
\text { above } \\
\text { Threshold }\end{array}$ & $\begin{array}{c}\text { Actual No. of } \\
\text { students on or } \\
\text { above Threshold }\end{array}$ & $\begin{array}{c}\text { Level of } \\
\text { Attainment }\end{array}$ \\
\hline $\begin{array}{l}\text { Part A+ }+ \\
\text { Assignment }\end{array}$ & $60 \%$ & $60 \%$ & & & & \\
\hline
\end{tabular}

Attainment Level $=(($ Col. $(6) /$ Col. $(4)) * 3)=$ B:

\begin{tabular}{|l|c|c|c|c|c|c|c|c|}
\hline COs & $\begin{array}{c}\text { No. Of } \\
\text { Students } \\
\text { Appeared }\end{array}$ & $\begin{array}{c}\text { Threshold } \\
\text { value }\end{array}$ & $\begin{array}{c}\text { Actual } \\
\text { Average }\end{array}$ & $\begin{array}{c}\text { Target \% of } \\
\text { students on or } \\
\text { above } \\
\text { threshold }\end{array}$ & $\begin{array}{c}\text { (1) } \\
\text { Target No. of } \\
\text { students on or } \\
\text { above } \\
\text { Threshold }\end{array}$ & $\begin{array}{c}\text { Actual \% of } \\
\text { students on or } \\
\text { above } \\
\text { Threshold }\end{array}$ & $\begin{array}{c}\text { Actual No. of } \\
\text { students on or } \\
\text { above } \\
\text { Threshold }\end{array}$ & $\begin{array}{c}\text { Level of } \\
\text { Attainment }\end{array}$ \\
\hline CO1 & & $60 \%$ & & $60 \%$ & & & \\
\hline CO2 & & $60 \%$ & & $60 \%$ & & & \\
\hline
\end{tabular}

$\mathrm{CO}$ Attainment $=(\mathrm{CO} 1+\mathrm{CO} 2) / 2=$

MID-I Attainment Level $=(\mathrm{A}+\mathrm{B}) / 2=$ 
MID- I I Exam Assessment:

Number of Students Appeared:

A:

\begin{tabular}{|l|c|c|c|c|c|c|c|}
\hline Assessment & $\begin{array}{c}\text { Threshold } \\
\text { value }\end{array}$ & $\begin{array}{c}\text { Actual } \\
\text { Average }\end{array}$ & $\begin{array}{c}\text { (3) } \\
\text { Target \% of } \\
\text { students on } \\
\text { or above } \\
\text { threshold }\end{array}$ & $\begin{array}{c}\text { (4) } \\
\text { Target No. of } \\
\text { students on or } \\
\text { above } \\
\text { Threshold }\end{array}$ & $\begin{array}{c}\text { (5) } \\
\text { Actual \% of } \\
\text { students on or } \\
\text { above } \\
\text { Threshold }\end{array}$ & $\begin{array}{c}\text { Actual No. of } \\
\text { students on or } \\
\text { above Threshold }\end{array}$ & $\begin{array}{c}\text { Level of } \\
\text { Attainment }\end{array}$ \\
\hline $\begin{array}{l}\text { Part A + } \\
\text { Assignment }\end{array}$ & $60 \%$ & & $60 \%$ & & & & \\
\hline
\end{tabular}

Attainment Level $=(($ Col. $(6) /$ Col. $(4)) * 3)$

B:

\begin{tabular}{|l|c|c|c|c|c|c|c|c|}
\hline COs & $\begin{array}{c}\text { No. Of } \\
\text { Students } \\
\text { Appeared }\end{array}$ & $\begin{array}{c}\text { Threshold } \\
\text { value }\end{array}$ & $\begin{array}{c}\text { Actual } \\
\text { Average }\end{array}$ & $\begin{array}{c}\text { Target \% of } \\
\text { students on or } \\
\text { above } \\
\text { threshold }\end{array}$ & $\begin{array}{c}\text { (3) } \\
\text { Target No. of } \\
\text { students on or } \\
\text { above } \\
\text { Threshold }\end{array}$ & $\begin{array}{c}\text { Actual \% of } \\
\text { students on or } \\
\text { above } \\
\text { Threshold }\end{array}$ & $\begin{array}{c}\text { Actual No. of } \\
\text { students on or } \\
\text { above } \\
\text { Threshold }\end{array}$ \\
\hline CO3 & & $60 \%$ & $\begin{array}{c}\text { Level of } \\
\text { Attainment }\end{array}$ \\
\hline CO4 & & $60 \%$ & & $60 \%$ & & & \\
\hline
\end{tabular}

CO Attainment $=(\mathrm{CO} 3+\mathrm{CO} 4) / 2=$

MID-II Attainment Level $=(\mathrm{A}+\mathrm{B}) / 2=$

Internal Assessment $=$ Mid- $\mathrm{I}+$ Mid-II $/ 2=$

External Assessment:

Number of Students Appeared:

\begin{tabular}{|c|c|l|l|l|c|}
\hline $\begin{array}{c}(\mathbf{1}) \\
\text { Threshold } \\
\text { value }\end{array}$ & $\begin{array}{c}(\mathbf{2}) \\
\text { Actual Average }\end{array}$ & $\begin{array}{l}\text { (3) } \\
\text { Target \% of } \\
\text { students on or above } \\
\text { threshold }\end{array}$ & $\begin{array}{l}\text { (4) } \\
\text { Target No. of } \\
\text { students on or above } \\
\text { Threshold }\end{array}$ & $\begin{array}{l}\text { (5) } \\
\text { Actual \% of students on or } \\
\text { above Threshold }\end{array}$ & $\begin{array}{c}\text { Actual No. of } \\
\text { students on or } \\
\text { above Threshold }\end{array}$ \\
\hline $60 \%$ & & $60 \%$ & & & \\
\hline
\end{tabular}

Attainment Level $=(($ Col. $(6) /$ Col. $(4)) * 3)=$

Attainment of Course: (25\% of Internal Attainment $+75 \%$ of External Attainment $)=$

\begin{tabular}{|c|c|}
\hline Course Attainment & Remarks \\
\hline & Moderate
\end{tabular}
* 1 - Slight
2 - Moderate
3 - Substantial 


\section{CONCLUSION}

In conclusion, more than $60 \%$ of every subject POs is successfully achieved. This is proved That if all direct survey exceeds $60 \%$ then we can say we have achieved Level 3.If Level 3 is Not reached then organization has to take initiation to conduct remedial classes, organizing Guest lectures to reach target level 3. If the indirect survey scores is not reached to target Level 3, Once students graduated from engineering college, they are all prepared to meet the Industry need. From this research, it is proven that the outlined PEO, PO, and generic skill for Every subject helps students to develop themselves. In other words, this evaluation method in OBE system helped to make students ready for industry and able to meet the future needs.

\section{REFERENCES}

[I] A A Aziz, MJ. Megat Mohd Noor, AA Abang Ali, and M.S. Jafar, "A Malaysian Outcome-based Engineering Education Model," in lot Journal of Eng. and Tech, Vol 2, Nol, 2005, pp. 14-21.

[2] A Sher, "Outcome-based Education in the way of the 21st Century",New Straits Times, Jun, 32009.

[3] National Higher Education Plan 2007-2010, Triggered Higher Education Transformation, Ministry of Higher Education, Appendix A, August, 2007.

[4] Kementerian Pendidikan Malaysia, "Pembangunan Pendidikan 2001-2010: Perancangan bersepadu menjana kecemerlangan pendidikan",

Kementerian Pendidikan Malaysia, Kuala Lumpur, 200 I.

[5] Kajian Separuh Rancangan Malaysia Kesembilan 20062010, Berita Harlan, April I, 2006

[6] Pelan Induk Latihan dan Kemahiran Pekerjaan Malaysia 2008-2010,"Tenaga Kerja mahir Memacu Daya Saing Global Malaysia", Kementerian Sumber Manusia, 2008. 